\title{
15
}

\section{From Innovations at Work to Innovative 2 Ways of Conceptualizing Organization: 3 A Brief History of Organization Studies 4}

\author{
Lise Arena and Anthony Hussenot
}

\section{Introduction}

While organizational scholars have recently investigated varied organiza- 7 tional phenomena, such as social movements, artistic activities, non- 8 profit organizations or informal collectives of people, mainstream 9 organization research has historically carried out empirical work in com- 10 panies, factories or networks of firms, ${ }^{1}$ mainly because of the dominance

\footnotetext{
${ }^{1}$ This proximity with business has led to a confusion between organization studies, management research (George 1968; Wren 1972) and the theory of the firm. Management research is interested in improving the economic performance of companies and organizations; the theory of the firm concentrates on the economic dimensions of firms. In this chapter, we suggest to highlight the distinction between organization studies, management research and the theory of the firm.
}

L. Arena (河)

Université Côte d'Azur, Nice, France

e-mail: lise.arena@univ-cotedazur.fr
A. Hussenot
Université Côte d'Azur, Antibes, France
e-mail: Anthony.hussenot@univ-cotedazur.fr

(C) The Author(s) 2021

N. Mitev et al. (eds.), New Ways of Working, Technology, Work and Globalization, https://doi.org/10.1007/978-3-030-61687-8_15 


\section{Arena and A. Hussenot}

of the industrial context after the Second World War. As such, organization studies are rooted in social sciences (such as economics, sociology and philosophy), and focus on the evolution of work and management practices. As most of social sciences, organization studies have evolved in line with society, and more specifically, business, managerial and work innovations. Consequently, the relation between innovations at work and the theoretical developments has led to different understandings of the matter of organization over time. If an organization was initially conceptualized as a social and/or economic entity evolving into an environment, this view has since been challenged by scholars. Recent organization theories have suggested to understand organization as an open phenomenon, always in a state of becoming. An organization is not conceptualized as an entity but as an elusive movement ongoing re/defined in practices. The initial essentialist view of organization was forged in a context of industrialization and mass production, dominated by Fordist practices, while the current elusive view of organization has emerged in the context of 'liquid modernity' (Bauman 2000) and the 'projectification' of work (Jensen et al. 2016).

In this chapter, we suggest studying the relation between work innovations and the evolution of organization theories. We emphasize the relation between management and work innovations and new ways of conceptualizing the matter of organization over time. The aim is to show how innovations at work have influenced the way scholars have conceptualized organizational phenomena over time.

We describe and analyze this relation from the 1950 s to the 2010 s. We study this relation through four periods covering the mass productionbased organization of the 1950s to the projectification of work of the 2010s. Of course, these periods are used for analytical purposes as each new period partly overlaps with the previous ones. 


\section{Period 1: The Development of Industrial Innovations-Theorizing Organization as a Centralized Managerial Hierarchy}

The period following the Second World War was marked by an unprec- 44 edented economic expansion in Western countries that depended on the 45 significant rise of consumption and national modes of capitalism (Arena 46 2011). Rising working-class prosperity led to mass consumption and Fordist mass production replaced manual work with machines leading to increased labor division and repetitive tasks. Social and technological 49 changes that shaped the second half of the twentieth century built on the 50 first industrial revolution in the nineteenth century; the second industrial 51 revolution was based on the development of organic chemistry, electricity 52 and nuclear physics in the first half of the twentieth century and molecu- 53 lar biology since the 1950s. Post-Second World War advances in engi- 54

AU4 neering, computer science and electronics also paved the way towards the third 'electronic' industrial revolution characterized by a smaller number of firms than the ones that shaped the second industrial revolution. These successive waves of inventions shaped industries all over the world, with Europe catching-up the US. The US developed innovations and gained competitive advantage in the computer (e.g. IBM) and car (e.g. General 60 Motors) industries. In the same period, Europe gradually caught up par- 61 ticularly in the chemical (e.g. Haber-Bosch) and car (e.g. Volkswagen) 62 industries in Germany and the transport industry in France (e.g. SNCF). 63 The UK differed slightly as industrial policy was limited and most inno- 64 vations appeared in the service industry (e.g. financial sector). 65 Organizational forms shaped by industrial innovations in this period 66 resulted from national characteristics: managerial capitalism in the US, 67 state-led nationalized enterprises in France, cooperative capitalism with 68 cartelization in Germany and proprietary capitalism with family-owned 69 businesses in the UK. 


\section{Centralized Managerial Hierarchies and the Rise of Professional Management}

To a large extent, the main characteristics of organizational forms in the post-Second World War period appeared as a continuity of inter-war managerial innovations. Business historian Alfred Chandler claimed that the structures of companies and the role of management played a significant part in the evolution of capitalism (Chandler 1990). Hence, US capitalism success could be explained by the ability of American managers to develop multidivisional enterprises, characterized by centralized hierarchies, administrative coordination and the rise of managerial services. By contrast, British managerial backwardness was due to the predominance of small firms (mostly family-owned businesses) and a small number of 'white collars'. ${ }^{2}$ Innovations were supported by "the new forms of transportation and communication [which] permitted the rise of modern mass production. [...] Thus, came into being a new economic institution, the managerial business enterprise and a new subspecies of economic man, the salaried manager" (Chandler 1990, 1). These organizations appeared as an alternative to decentralized market mechanisms and they routinized transactions among units, lowering their costs. Organizational models were based on administrative coordination and task specialization that allowed product specifications and market services to be adjusted more rapidly to customer needs. At the management level, salaried middle and top managers supervised and controlled the different units. As a result, management became a profession with a direct interest in organization (and innovation), in contrast to shareholders who were still generally driven by short-term profit interest.

Based on this vertical integration model inherited from Frederick Taylor's "Principles of Scientific Management" (first published in 1911) and labor division popularized by Henri Ford, managers and workers of the 1950 s took part in a large transformation of work practices. On the one hand, control was placed at the center of managerial corporations, as

\footnotetext{
${ }^{2}$ Based on historical case studies (monographs) of the 200 largest US, UK and German firms, Chandler's study showed the rise of professional managers and 'organization men' as a new category of businessmen (Chandler 1990).
} 
managers of multidivisional units were the guardians of standardized 102 methods. The professionalization of management and the emergence of 103 salaried managers justified the development of management education in 104 the US and in Europe which soon became an urgent need to train this 105 new category of businessmen (Arena 2011). Yet, over the 1960s, the top- 106 down understanding of control gradually faded away to allow more room 107 to a consensual view of the employment contract in which workers could 108 develop further adaptability and gain welfare.

On the other hand, the inheritance of Taylor's methods stimulated labor movements which later encouraged the consideration of employees' 110 working conditions and the creation of research committees in America and in Britain to address the 'labor problem'. During the inter-war period, 'labor problems' were due to high turnover, high absenteeism and low workers' motivation and drove employers in large businesses to think about the relationship between workers' welfare and productivity. It was in this context that a number of American firms-such as Proctor \& Gamble, General Electric, Eastman Kodak and U.S. Steel-began to develop a range of new initiatives about work welfare that took the form of financial and non-financial measures. ${ }^{3}$

\section{Pioneer Organization Theories: The Tavistock Institute, the Aston Group and the Carnegie School}

Pre-1945 ideas about management and organization developed by engineers such as Henri Fayol, Henri Ford and Frederick Taylor equipped 123 enterprises with new forms of labor specialization that were disseminated beyond America, as the most efficient mode of organization in industrial factories. Although Europe never witnessed a 'scientific management' movement like its American equivalent, Taylorism and Fordism still received a fair amount of attention, mainly positive, by British, French

\footnotetext{
${ }^{3}$ This included measures to improve basic working conditions (e.g. provision of shower rooms, cafeterias and drinking fountains), to enhance workers' sense of being part of a factory team (e.g. publication of company magazines, organization of educational lectures and athletic clubs), to recognize seniority in employment status (e.g. bonuses, pension plans, medical assistance and company housing) and to provide training opportunities (e.g. vocational schools and apprenticeship programs) (Moriguchi 2000, 13-14).
} 


\section{Arena and A. Hussenot}

and German engineers (Chevalier 1937; Whilston 1997). Moreover, the theoretical analysis of bureaucracy by sociologist Max Weber (1922), translated and expanded upon by Talcott Parsons $(1942,1947)$ and Robert Merton (1949/1968), played an important role in the development of early organization theories (Shenhav 2003). This is exemplified by the publication of the first academic articles about organization such as the work of sociologist Philipp Selznick who published An Approach to a Theory of Bureaucracy in 1943 and Foundations of the Theory of Organization in 1948. In the same period, Herbert Simon published in 1947 American Behavior: A Study of Decision-Making Processes in Administrative Organization. As a result, new modes of organization in industrial factories and pioneer publications in the field led to the emergence of three major schools of thought: The Tavistock Institute (London, UK), the Aston Group (Birmingham, UK) and the Carnegie School (Pittsburgh, US).

\section{The Tavistock Institute: The Working Group as a Sociotechnical System}

The first wave of reactions to the scientific method of organizing enterprises comes from the 'human relations' movement. This movement was exemplified by the Hawthorne studies - some of the best known and most influential investigations in the history of organizational researchthat took place at the Western Electric Company (US) between 1927 and 1932. In the same period, the French industrial engineer Henri Fayol (1916/1949) put a greater (than Taylor) emphasis on the management level (and less on the workers) and discussed the aim of the managerial function. ${ }^{4}$ Management anticipates actions (planning), aims at structuring the organization (organizing), disseminates orders (commanding), guarantees the coherence of actions (coordinating) and checks results (verifying).

\footnotetext{
${ }^{4}$ Fayol was the managing director of the French Commentry-Fourchambault et Decazeville Company (a large mining and steel firm) for 30 years (1888-1918). Fayol's initial contribution (Administration Industrielle et Générale, published in French in 1916) was translated into English in 1930 by J. A. Coubrough, and then by J. Storrs in 1949 with the title General and Industrial Management.
} 


\section{From Innovations at Work to Innovative Ways...}

Social psychology of work and early studies on groups as organizations 159 went one step further and significantly rose in the UK in the 1960s. In particular, Eric Trist, with a number of colleagues in the Tavistock Institute (such as Emery, Rice and Miller), conducted a series of investigations into groups and organizational functioning. Their main contribution to the emergence of organization studies led to a 'system approach' to organizational behavior. In particular, they showed that working groups were neither a social system nor a technical system but an interdependent sociotechnical system. In their view, the traditional technocratic bureaucracy is limited when organizations have to face turbulent and innovative environments. Control systems could be seen as cumbersome and costly even if, thanks to this control, an unskilled worker in a narrow job is inexpensive to replace and takes little time to train. As early as the 1960s, these authors suggested alternative organizational designs for turbulent environments in which "individuals and units have wide repertories of activities to cope with change", and an improved quality of working life "by keeping the technological determinants of worker behavior to a minimum to satisfy social and psychological needs by the involvement of all" (Hickson and Pugh 2007/1964, 153).

\section{The Aston Group: The Structure of Organizations}

The structuralist view was deeply anchored in Max Weber's contribution to sociology and its translation in English by Talcott Parsons. A small 180 interdisciplinary (social psychology, sociology, anthropology, political sci181 ence and economics) group of researchers (1961-1970) at the University 182 of Birmingham in the UK echoed this initial trend and sought to under183 stand variables influencing organizational structures (such as technology, 184 size, environment and culture). ${ }^{5}$ Aiming to make a contribution to the interdisciplinary study of management behavior, the Aston group tested the idea that organization structure fits its operational context (Greenwood and Devine 1997, 202). Based on a statistical analysis, the group, whose principal investigators were Derek Pugh and David Hickson, collected

${ }^{5}$ Further details about the history of organization and management studies at Birmingham can be found in Minkes (2011). 


\section{Arena and A. Hussenot}

190 firms' data that enabled them to build organizational taxonomies. In this sense, the Aston Group's contribution to organization theory also has to be assessed at a methodological level since it was seen as "somewhere in between the tracing of processes over time in early "one case-studies [...] and the postulating of causal explanations informed by wider sampling" (Pugh and Hickson 1972, 273). Their willingness to develop from a descriptive to an analytical discipline led the Aston research team to initiate 'strategic contingencies theories' in a research cooperation with the University of Alberta in Canada.

\section{The Carnegie School: Decision-Making Processes in Organizations}

In the last chapter of his book The Functions of the Executive published in 1938, Chester I. Barnard, President of the New Jersey Bell Telephone Company at the time, observed that there was a need for "a science of organization" (Barnard 1968/1938, 290). ${ }^{6}$ The publication of Herbert Simon's Administrative Behavior in 1947 explicitly relied on Barnard's effort to develop a science of organization. Simon's initial ambition was to formalize Barnard's contribution from a conceptual perspective. $\mathrm{He}$ sought to "describe, in words, exactly how an administrative organization looks and exactly how it works" (Simon 1947). Simon's concept of 'bounded rationality' directly contributes to the development of organizational theory, as organizations are seen as useful instruments "for the achievement of human purpose". ${ }^{7}$ Organizations are therefore seen as a way to economize on cognitive resources, seen as scarce in a context of bounded rationality. Simon discussed innovation in relation with a

\footnotetext{
${ }^{6}$ Barnard identified this gap in social sciences: "there is no science of organization or of cooperative systems; and the development of the sciences called social has clearly lagged far behind those called physical and mathematical. One reason for this appears to be a false emphasis upon intellectual and mental processes both as factors in human relations and as matters of study" (Barnard 1968/1938, 290).

${ }^{7}$ Herbert A. Simon challenged the well-established concept of 'perfect rationality' used at the time in economics. For him, human cognitive capabilities are limited in information and knowledge and cannot formulate a 'rational' choice resulting from an optimization process. Humans simplify their choice process and can do so when replacing the goal of 'maximizing' with the goal of 'satisficing'.
} 


\section{From Innovations at Work to Innovative Ways...}

problem-solving framework. Innovation (technical or organizational) is 215 seen as a significant process in the expansion of firms. As innovation and 216 creativity are a type of complex problem-solving, he argued that it could 217 be captured in terms of simple heuristics and satisficing criteria (by con- 218 trast with optimization which was the predominant paradigm in eco- 219 nomics at the time). Simon's contribution to 'design science' paved the 220 way towards new models of innovations mainly based on knowledge 221 transfers and information-based approaches.

To a large extent, the publication of Simon and March's book on Organizations in 1958, and Cyert and March's book in 1963, imported innovation issues in organization theories. In particular, Cyert and March argued that their general theory was "of considerable relevance to the prediction of innovations" $(1963,278)$. They focused on the notion of failure and argued that firms innovate both when successful and unsuccessful. In the case of successful firms, the existence of organizational slack allows resources to be channeled towards innovative activities. In the same vein, they showed that, in service organizations, managers "pre223 224 225 226 227 228 229 230 fer to copy the ideas of others or to search for ready-made solutions 231 instead of seeking innovation" (Nutt 1984, 445). They linked innova232 tions with the concept of 'organizational learning', as firms revise their 233 search procedures on the basis of experience (Cyert and March 1963, 124). 234

This first period (1950-1980) constituted the rise of management as a profession with "concepts, research methods, and specialized techniques of practice that could be studied, taught, communicated and improved by the acquisition of scientific information" (Scott 1992, 25). Organizations were seen as administrative entities and closed systems in which innovation was attributed to the visionary capacities of top manag235 236 237 238 239 240 ers. As rightly stated by Slappendel $(1996,110)$, in this perspective, "the 241 actions of individuals are not seen to be constrained by external factors, 242 instead individuals are perceived to be self-directing agents who are 243 guided by the goals that they set". 


\section{as a Learning Institution}

The second period of analysis is concerned with the development of the 'electronic' century (Cortada 2011), also characterized as the second wave of the Information Technologies (IT) revolution enabled by the advent of the personal computer during the 1980s and the Internet during the 1990s (Porter and Heppelman 2014). Innovations are essentially immaterial and developed within the context of a global knowledge economy, with distributed supply chains easing coordination and integration across activities. From the 1980s onwards, large managerial corporations turned into innovative enterprises characterized by coordinated business organizations that adopted technologies and learned to adapt in a context of high uncertainty and turbulence. In the US, the Management in the 1990s Research Program, a close collaboration between academic researchers at the MIT Sloan School of Management and representatives of major corporations, represents the organizational archetype of the 1990s and their organizational, work and technological innovations. The final report of the program strongly emphasized the role of information in the evolution of 1990s firms (Scott Morton 1991). Information was considered, for the first time, as a fourth factor of production: "as an 'information engine', it can do for business what the steam engine did in the days of the Industrial Revolution" (Scott Morton 1991, 8). The diffusion of IT implied potential organizational change, as it offered the opportunity for organizations to react constructively to environmental turbulence. In the 1980s, most technological innovations were concerned with hardware, software, networks, workstations robotics and smart chips. These information-based technological innovations gave firms the opportunity to lower their operating costs while improving their efficiencies (Cortada 2011; Porter and Heppelman 2014). For example, in the 1990s, the emergence of supply-

277 chain enhanced the coordination of work and the management of flows 278 of goods, supplies, processes and expenses within the organization. 


\section{The Knowledge-Based Economy and Horizontal Informational Structures of Companies}

While the US economy had a significant competitive advantage with a well-established IT industry composed of large corporations such as IBM and Microsoft, the Japanese computer industry arose in the 1980s, from capabilities developed in long-established firms making electrical and telecommunications equipment, such as Fujitsu Limited or Toshiba Corporation. This has to be understood in relation with the evolution of Japanese capitalism based on financial business and conglomerates. The Japanese industrial success of the 1980s was mainly explained by national specificities such as stable shareholding, permanent employment and main-bank lending (Lazonick 2010). In his comparison of two archetypal firms (the American and the Japanese models), the economist Masahiko Aoki observed the rise of the Japanese economy in the 1980s and explained it through a shift from primary and secondary activities (agriculture and manufacturing) to information-based production (telecommunications and computers ${ }^{8}$ ). The Japanese organizational model paved the way towards a knowledge-based economy ${ }^{9}$ characterized by flexible specialization, mass customization and lean manufacturing. The shift from a vertically integrated organization to a more flexible way of organization is largely rooted in the archetype of 1980s Japanese firms.

The development of horizontally coordinated organizations led to various changes in the nature of work. This period constituted a breaking point with the Fordist era. "The heightened expectations of people in Western Europe and North America are giving rise to pressures to improve

\footnotetext{
${ }^{8}$ This phenomenon was also observed in the US to a lesser extent at the time under the term "Post-Fordism".

${ }^{9}$ While embryonic approaches of information and knowledge-based organizational theories originated in the 1960s, they only became popular 30 years later. One example of this theoretical trend is probably the dissemination of resource-based approaches to the firm as a result of Edith Penrose's early contribution to organizational theory. In her 1959 book, entitled The Theory of the Growth of the Firm, Penrose views firms not like standard economists of her time as price (and output) takers whose access to extra-profits is limited to situations of high degrees of market power (imperfect competition). Instead, she emphasizes that the firm is a device for innovation, problem-solving and cumulative learning through production. She underlines the idea of an endless knowledge-creating process and argues that "the very processes of operation and of expansion are intimately associated with the process by which knowledge is increased" (Penrose 1959, 125).
} 


\section{Arena and A. Hussenot}

304 the quality of working life and the quality of the environment. This is resulting in a changing concept of what constitutes value" (Scott Morton $1991,3)$. In addition, cooperative work enabled by IT tended to alter most tasks in organizations, as the primary objective of organizations moved to coordinate the delivery of goods and services to customers. As a result, traditional roles of managers changed, as employees had "more access to data, they will take over many of the functions associated with supervisors" (Osterman 1991, 236). Managers had to learn to share their knowledge of the production process and of technologies with less qualified workers. As teams became a more common organizational form within firms, workers also had to learn new roles and skills. Jobs were no longer specified in detail and workers had to rotate among various jobs, and the development of skills and tacit knowledge became key to firms' strategies.

New challenges faced by organizations involved a need to train high skilled workers and to develop a 'learning organization'. Therefore, knowledge gradually became one of the most important assets in the development of firms' competitive advantage. The practice of knowledge management was introduced as "the identification, optimization, and active management of explicit or tangible informational assets (such as data physically stored in a computer or on a piece of paper) and tacit knowledge (information and insights residing largely in people's heads)" (Cortada 2011, 24). In line with this knowledge-view of the organization, communities of practice emerged as triggers to collective 'learningby-doing' and started attracting scholars' attention (Lave and Wenger 1991). New forms of learning organizations rely on the growth of communities of practice with people who share a concern or a passion for something they do and learn how to do it better as they interact regularly.

Reinforcing the Mainstream or Being Against? Perspective in Organization Studies 


\section{From Innovations at Work to Innovative Ways...}

during the 1980s and 1990s to either reinforce the mainstream perspec337 tive in organization studies or disrupt it by introducing alternative ways 338 of defining and studying organization. To exemplify this tension in the field, the following section introduces the neo-institutionalism, the postmodernism and the critical management studies.

\section{Neo-institutionalism: Isomorphism and Legitimacy}

From the 1950s, the notion of 'organizational behavior' has been domi343 nant in organization studies. The premise of organizational behavior 344 studies is that an organization is an entity that can (almost) behave on its 345 own. However, others have argued that society and institutions influence 346 this behavior. During the late 1970s, a new form of institutionalism, 347 called 'neo-institutionalism', emerged to understand how organizational 348 behavior is situated and influenced by other organizations and wider 349 social forces (Lounsbury and Zhao 2014). For these scholars, any organi350 zation evolves in communities of organizations that interact with each 351 other (DiMaggio and Powell 1983). These interactions create an institutional logic', that is symbolic and material elements tied together and 352 providing order and meaning (Friedland and Alford 1991). According to 353 the neo-institutionalist view, organizations conform to institutional pre354 scriptions to gain legitimacy with key audiences (Meyer and Rowan 355 1977). Legitimacy is understood as immaterial capital enhancing status, 356 reputation and survival chances (Rao 1994). Organizations implement 357 innovations as a way to conform with institutional logics, and not neces358 sarily because of requirements of technical, human or financial efficiency. 359 These institutional pressures lead to 'isomorphism' among organizations, 360 that is organizations imitate each other by adopting common structures, 361 practices and technologies (Meyer and Rowan 1977). Unlike organiza362 tion theories developed in the first period, the focus of neo-institutional 363 theory is not the relation between the organization and its environment, but rather networks of organizations, such as innovation systems. 


\section{Arena and A. Hussenot}

367

368

369

370

371

372

373

374

375

376

377

378

379

380

381

382

383

384

385

386

387

388

389

390

391

392

393

394

395

396

397

398

399

400

\section{Postmodernism: The Role of Language in the Emergence of Organizational Phenomena}

As much as neo-institutionalism can be understood as expanding mainstream organization studies, the postmodern perspective was developed by some scholars in organization studies during the 1980s and the 1990s and initiated a radical change in the way organization has been studied since. However, the notion of postmodernism covers at least two different meanings: postmodernism (without a hyphen) as a way of studying organizational phenomena (Cooper and Burrell 1988; Burrell 1994; Cooper 1989; Chia 1995, 2003; Parker 1992); and the postmodern organization (with a hyphen) as a type of organization emerging during the 1980s and the 1990s (Clegg 1990).

Postmodernism is rooted in European philosophy of the 1970s and 1980s, in particular the French theories of Jacques Derrida, Michel Foucault and Jean-François Lyotard, among others. The postmodern view insists on the role of language in constituting organizational phenomena. In such a view, there is no ultimate truth about organization and management but only forms of discourses. Postmodernism is thus based on a critique of positive and normative science seeking laws for good practices, which is the foundation of modernist organization studies and management. Instead, postmodern scholars urge scholars to study the situatedness of organizational phenomena and how they are performed through discourses.

The postmodern perspective characterizes a new form of organization as flexible and niche-marketed and based on a multi-skilled workforce held together by IT networks and outsourcing (Clegg 1990, 181). These new organizational forms are claimed to be innovation-oriented, organizational structures flexible with no clear center of power or spatial location. Japanese innovative working methods illustrate the postmodern organization. Japanese engineers designing products followed the product from the lab to the manufacturing facility (Aoki 1990). Workers had to become capable of coping with unexpected emergencies as managers increasingly delegated their decision-making power. Knowledge had to be shared and the new challenge was the codification and transmission of 
tacit knowledge from expert to non-expert workers, and the organization had to develop learning and adaptation capabilities, rather than concentrate on minimizing transaction costs. This organizational form follows a just-in-time production process which begins when customers order a product and in which each worker has skills to adapt to this new type of production.

401

402

403

404

405

406

\section{Critical Management Studies: The Deconstruction of Hidden} 407 Assumptions in Management

Partly based on the postmodern turn, some scholars have started to question the assumptions of management both as an academic discipline and as a practice. This has led to the emergence of critical management studies (CMS), first initiated by Alvesson and Wilmott (1992). According to critical management thinkers, modern management is mainly instrumental and only serves the profit of companies (Adler et al. 2008). Innovations at work such as improvement of working conditions, selfdevelopment and self-determination are only adopted by companies if they help to improve business performance. This raises ethical and political questions regarding the value of such ends, and consequently, the responsibility of scholars reinforcing such practices through normative research and teaching. "CMS aims to show how such beliefs and practices are nurtured by, and serve to sustain, divisive and destructive patterns and structures; and also, how their reproduction is contingent and changeable, neither necessary nor unavoidable" (Adler et al. 2008, 3). CMS aim at denunciating the instrumentalism, patriarchism, racism, imperialism, productivism (etc.) that are inherent in modern management.

409

410

411

412

413

414

415

416

417

418

419

420

421

422

423

424

425

\section{Period 3: Liquid Modernity-Theorizing Organization as a Movement}

In 2000, sociologist Zygmunt Bauman published a book called Liquid 428 Modernity. This book marked a turning point in social sciences as his key 429 idea is that we have been entering a society in which the core institutions 430 


\section{Arena and A. Hussenot}

431 are diluting. The expression 'liquid modernity' was a way to express one 432 of the main trends of our society: the liquefaction of social institutions. 433 For Bauman (2000), this liquid modernity means that individuals can 434 rely only on themselves as their relations with others are uncertain, evolv435 ing and temporary. Jobs, family, friendships are becoming more and more uncertain, often in a state of flux. There are many explanations for this liquefaction of society and some of them can be found in the countercultures of the 1960s and 1970s, when people started to free themselves from rigid social orders (religion, patriarchism, patriotism, etc.). However, in the 2000s, the world became more globalized than ever, with largescale exchanges between people. With the end of the Soviet Union at the beginning of the 1990s and market deregulation all over the world, cultures and economies became more globalized and a reality that people could experience in their daily life. This globalization generated a period of economic growth and social development for many countries, but at the same time, an intensification of competition between companies. Outsourcing, offshoring, mergers and acquisitions were the main conse448 quences of this fierce global competition.

\section{Innovation as the Main Driver in Management}

To face these threats, companies had to innovate constantly, again and again. This has become a motto in many sectors. Of course, innovation had been a key activity for companies for decades, but the novelty became the intensity of innovation. Instead of waiting for the end of their products' life cycle before launching a new one, companies started to constantly launch new products on the market as a way to beat competitors. This period of development coincided with the second wave of IT-driven transformation, characterized by the rise of the Internet with its cheap and ubiquitous connectivity (Porter and Heppelman 2014). This led to enhanced coordination between suppliers and customers across space and time.

This innovation intensity is not only the result of increased competition, it is also the sociological consequence of the liquefaction of society. As people's identity was no longer based on belonging to institutions 
(company, family, state, etc.), mass consumption became a way to define oneself (Bauman 2000). Consumption is motivated by the desire to become someone and belong to groups sharing the same consumption. As innovation became the only way to make business, management and work practices became more knowledge-oriented in order to generate more ideas. This is referred to as the knowledge-based economy, an economy in which knowledge is considered as the core asset and provides competitive advantage for companies. The 2000s was the age of knowledge management, competencies management, communities of practices, learning organizations. All of these notions and managerial practices have aimed at ensuring constant learning, sharing, storing and creation of knowledge for the sake of innovation. Technologies also played an important role in this evolution, as the fast development of the Internet during the 1990s and 2000s and the constant improvement of computers and infrastructures have enabled people to work together and access large amounts of information. These technological developments also participated in the innovation race. Information systems management became another crucial area for companies, as information systems were considered a key element to compete in this knowledge-based economy.

464

465

466

467

468

469

470

471

472

473

474

475

476

477

478

479

480

481

482

483

484

Facing this globalized world in which companies were constantly evolving, merging with each other, diversifying their activities, competing and partnering on a global level, organizational scholars could not rely on the essentialist view of organization any longer-the organization as an economic or social entity. Inspired by postmodernism in organization studies (Parker 1992; Chia 1995, 2003), but also by feminists Judith Butler and Karen Barad and posthumanists Andrew Pickering and Bruno Latour, organizational scholars shifted from a quest to develop ultimate explanations about the organization to developing organizational 'mindAU11 sets' (Cabantous and Sergi 2018), that is a way to provide plausible accounts about how organizational phenomena are produced and maintained on a daily basis by actors. An organization is no longer a company
485

486 487 488 489 490 491 492 493 494 495 496 


\section{Arena and A. Hussenot}

497

498

499

500

501

502

503

504

505

506

507

508

509

510

511

512

513

514

515

516

517

518

519

520

521

522

523

but a constant process of defining outputs and inputs of activities. Chia $(1997,1999)$ expanded on this idea arguing that organization is a process of world-making. An organizational phenomenon is an ontological activity that consists in defining the world, a situated definition of the world in order to act. By distinguishing the notions of organization as an ontological activity from company as a legal object, the study of organizational phenomena belonging to this globalized world became possible.

These mindsets are based on two core premises. The first is the primacy given to action, what people do. Organizational phenomena emerge and are maintained only through action. This moves away from the essentialist view that gave primacy to the organization. The second premise is based on relational ontology (Slife 2004; Cooper 2005). Relational ontology means that everything exists only in relationship to other things. 'Things' have not inherent properties and their singularity emerges from their interrelatedness. Interrelatedness is not passive and imposed on 'things'. According to the principle of action, it is in action that technologies, rules, roles, statuses and so on are mutually defined. Many 'mindsets' have been developed based on these two premises: performativity (Gond et al. 2016), the narrative approach (Rantakari and Vaara 2017), the communication constitutive organization (Cooren et al. 2011), the process view (Langley and Tsoukas 2010), the practice-based view (Gherardi 2012), sociomateriality (Orlikowski and Scott 2008) and so on. They all put action first, but have suggested different foci, such as language, social practice or technologies. As a way to exemplify this stream of research, we outline below three key 'organizational mindsets': the process view, the practice-based view and sociomateriality.

\section{The Process View: Understanding Organization as a Movement}

The process view is anchored in postmodernism and process philosophy which draws on various philosophers from the pre-Socratic Greek philosophy of Heraclitus to the metaphysics of Alfred North Whitehead, the American pragmatism, German phenomenology, Henri Bergson, Gilles Deleuze and so on (Rescher 1996, 2001; Helin et al. 2014). Their key assumption is that reality is constantly flowing and we cannot really grasp 


\section{From Innovations at Work to Innovative Ways...}

it, but only create images as a way to make it tangible and actionable 530

AU12 (Bergson 2009/1907). Cooper (1976, 2005, 2007, 2014) and Chia 531 (1995, 1997, 1999, 2003) defined key principles of the process view. 532 Action and relational ontology are two of them, but the originality has 533 been to add the principle of immanence (Chia 1999). Immanence means 534 that everything exists in the current moment. The past, the present and 535 the anticipated future are not a series of separate events, but are co-defined 536 and co-redefined in the current moment. In other words, past events can 537 always be reinterpreted according to the evolution of action, while antici- 538 pated events can always be redefined. It means that current action always 539 brings the past, present and anticipated events. Key challenges of process 540 organization scholars are to understand constant change (Tsoukas and 541 Chia 2002) and how 'things' occur and are maintained in a constantly 542 flowing world.

\section{The Practice-Based View: Understanding Organization from Practices}

The practice-based view is the second main mindset that has influenced organization studies since the 2000s. Practice-based studies are rooted in 546 the work of various sociologists and philosophers such as Bourdieu (1972, 547 1980), Lyotard (1979), Foucault (1980), Taylor (1995) and Giddens 548 (1979, 1984). Pierre Bourdieu and Anthony Giddens can be considered 549 as the key inspirations for organizational scholars. For Bourdieu (Bourdieu 550 551

AU14 1980), the world is made objective through practices, while Giddens (1984) insists on the role of social practices in the making of social struc552 tures. The main assumption of the practice-based view is that organizational phenomena are not given but emerge and are maintained through practices (Schatzki 1996, 2001; Corradi et al. 2010). For these authors, the practice-based view is thus a "way of seeing", with the aim of understanding "the situatedness of practical reasoning and the contingent nature of organizational rationality" (Corradi et al. 2010, 268). However, the concept of practice is difficult to define as practice can be anything participating in the shaping of the social world. Generally speaking, prac553 554 555 556 557 558 559 560 tice is simply what actors do with rules, words or things. The 561 562 


\section{Arena and A. Hussenot}

563 practice-based view is about understanding how everyday activities pro564 duce, reproduce or transform social structures "that are at the heart of 565 collective action" (De Vaujany et al. 2016a, 25). Consequently, the unit 566 of analysis becomes what actors do, or make visible through their actions.

567

568

569

570

571

572

573

574

575

576

577

578

579

580

581

582

583

584

585

586

587

588

589

590

591

592

593

594

595

\section{Sociomateriality: The Relation Between the Social and the Material}

During the 2000s the matter of materiality regained popularity among organizational scholars, partly due to the ubiquity of technologies at work. A stream of research called sociomateriality (with or without a hyphen) emerged as a way to study the entanglement of the social and the material. Mainly anchored in agential realism (Barad 2003, 2007), posthumanism (Pickering 1995), actor-network theory (Latour 2005) and the practice-based approach in organization studies (Orlikowski 2000), studies focused on how the social and the material gain status and roles through their intertwining in practice (Orlikowski and Scott 2008; Introna 2013; Jones 2013; Shotter 2013). Here again, primacy is given to action and the relational ontology. Entities "have a shared being and a mutual constitution" (Slife 2004, 811). From this entanglement perspective, any separation is merely analytical (Orlikowski and Scott 2008), as what we call the technical, the social and the organizational are mutually constitutive, only existing as doing (Shotter 2013) in their radical otherness (Introna 2013). The core question of this research stream has been how 'matter matters', and more importantly how entities matter in practices, how forms and their relations appear (Jones 2013, 223).

These mindsets can be considered as renewing ontological debates about organization. However, they have been confronted to their own contradictions about the ontology of organizational phenomena. Contradictions have come from the way scholars have dealt with relational ontology. In most of these mindsets, scholars' work can be divided into two groups: advocates of a weak relational ontology versus advocates of a strong relational ontology (Slife 2004). In the weak relational ontology, 'things', such as actors, technologies, roles, statuses, have their own existence. Despite their interaction and imbrication, 'things' remain 
distinct, interdependent phenomena. Strong relational ontology states that 'things' do not exist on their own but are entangled and intertwined; 'things' gain status only through their interpenetration and intra-action (Barad 2003). A more managerialist view of these mindsets has also emerged. Anchored into weak relational ontology, it has attempted to provide managerial contributions as a way to help companies face economic challenges. This can be found in various research streams in between management research and organization studies, such as strategyas-practice, community-of-practice, sociomateriality (with a hyphen) and the weak process view dedicated to the understanding of the innovation process.

596

597

598

599

600

601

602

603

604

605

606

\section{Period 4: Working and Collaborating Without a Company-Current Developments in Organization Studies}

In 2008, the financial crisis revealed an ugly truth to the world. The 610 banking system had played dangerously with people's money leading to a 611 dramatic economic crisis, seizure of properties, bankruptcies, unemployment and so on. The consequences were dreadful and governments all over the world tried desperately to contain the crisis. This crisis made more visible social challenges such as wealth inequality and unemployment. This led to an unprecedented crisis of faith that has since nurtured various social movements and political extremism. At the same time, environmental challenges have become more urgent. Climate change, scarcity of resources, pollution, loss of biodiversity, deforestation have started to question the industrial and mass-consumption model. The risk of a global collapse is considered a serious scenario by numerous scientists. In such a context, a rather young, educated, globalized and progressist elite-often ironically called hipsters_- has been experimenting with alternative lifestyles and new ways of working, living and consuming. Living and gentrifying neighborhoods of big cities, such as East London, they have developed a new economy called the 'flat-white economy' by McWilliams (2015), based on alternative ways of manufacturing and 612 613 614 615 616 617 618 619 620 621 622 623 624 625 626 627 


\section{Arena and A. Hussenot}

628

629

630

631

632

633

634

635

636

637

638

639

640

641

642

643

644

645

646

647

648

649

650

651

652

653

654

655

656

657

658

659

consuming. Veganism, eco-friendly products, the sharing economy, personal development have become some of the key trends; while the development of new digital and mobile technologies such as social media, smartphones and high-speed mobile networks enable them to develop their business from anywhere.

\section{Against the 9 to 5 Office Job: The Lifestyle Entrepreneurship}

These people are the tangible manifestation of many changes in society, especially at work. They tend to reject the traditional employment culture, that is 9 to 5 office hours, the hierarchy, job titles and the perks among others, and embrace lifestyle entrepreneurship, that is a strong belief in self-empowerment through entrepreneurship. Many terms have been proposed to name these new workers: mumpreneurs, makers, digital nomads, creative freelancers, influencers, coworkers, solopreneurs and so on. Most of the time they are independent workers, working collaboratively with other independent workers or companies. They reinvent ways of collaborating by relying on online platforms or social media or joining a shared working space such as a coworking space or a makerspace. Hypothetically they can work where and when they want, on the projects they want to, with whom they want and with no subordinate relation with anyone (Hussenot and Sergi 2018). This 'lifestyle entrepreneurship' also means that work and life are not separate activities any longer, and the entrepreneurial activity serves a lifestyle. The notion of 'workation' is a good example of this renewed relationship between work and life as it expresses the idea that work and vacation could be experienced at the same time. However, this idealistic scenario (as it has often been depicted on social media, blogs and press articles) has been tarnished by the so-called gig economy-short-term tasks-based activity carried out by independent workers - which has brought uncertainty and financial insecurity to many workers (Acquier et al. 2017). Car drivers and riders delivering food are two of the most common examples of this gig economy in which workers are paid per task. 


\section{Theorizing Organization Without a Company: Towards New Challenges and Frameworks in Organization Studies}

660

661

662

In such a fast changing and interrelated world, theories and mindsets developed during the 2000s have served as a core background for organizational scholars. There is still a need for strong philosophical and social theories as foundations to understand current trends. Critical management studies, the process view, practice-based theory and the performativebased view are still playing an important role in the intellectual debate. Awareness of this changing global context has encouraged organizational scholars to research new topics such as social movements (Haug 2013; Yousfi 2013), bikers' collectives (Wilhoit and Kisselburgh 2015) or terrorist networks (Schoeneborn and Scherer 2012; Stohl and Stohl 2011). Traditional topics such as management and work are explored through the lens of these global trends; changing work practices are happening outside of big companies and often deal with social, economic and environmental challenges. For instance, freelancers, makers and coworkers question our assumptions about working space, working time, but also collaboration, leadership, collective identity, power relations and so on and traditional dualisms such as work versus life, social concerns versus economic ones, companies versus their environment and so on. These dualisms seem to disappear in our interrelated world. Social, environmental and economic challenges have been at the heart of debates for the last decade and the study of companies has become less of a priority. This

AU15 has been called the 'societal turn in organization theories' (De Vaujany et al. 2016b). Recent themes addressed at the European Group for Organization Studies conferences (the main European research association in organization studies) speak for themselves: 'Bridging continents, cultures and worldviews' (2013), 'Reimagining, rethinking, reshaping: Organizational scholarship in unsettled times' (2014), 'Organization and the examined life: Reason, reflexivity and responsibility' (2015), 'The good organization: Aspiration, interventions, struggle' (2017), 'Enlightening the future: Challenge for organization' (2019) and
663 664 665 666 667 668 669 670 671 672 673 674 675 676 677 678 679 680 681 682 683 684 685 686 687 688 689 690 691 692 


\section{Arena and A. Hussenot}

693

694

695

696

697

698

699

700

701

702

703

704

705

706

707

708

709

710

711

712

713

714

715

716

717

718

719

720

721

722

723

724

725

'Organizing for a sustainable future: Responsibility, renewal and resistance' (2020).

Theoretically speaking, the current challenge is to envisage organizational phenomena not only as open but also fluid (Schreyögg and Sydow 2010), where activities and relationships are constantly evolving, members are not clearly identified and boundaries are open or permeable (Blagoev et al. 2019; Dobusch and Schoeneborn 2015). In such organizational phenomena, work can be done not only anywhere and at any time, but in multiple spatialities and temporalities. Another challenge is to conceptualize organizational phenomena with no separation between work and life. This is, for example, the case with influencers who have built their business based on their private life (Duffy 2016), or digital nomads who have decided to travel the world, while their professional activity is carried out exclusively remotely (Nash et al. 2018). As a way to understand these open and fluid organizational phenomena, new theoretical concepts have been suggested recently. For instance, the concept of 'organizationality' (Dobusch and Schoeneborn 2015; Schoeneborn et al. 2019; Blagoev et al. 2019) and the events-based approach (Hernes 2014a, b; Hussenot and Missonier 2016; Hussenot 2019; Hussenot et al. 2020).

\section{Organizationality: Understanding Organization as an Adverb}

In 2015, Dobusch and Schoeneborn introduced the notion of organizationality to understand how organizational dynamics manifest themselves in fluid organizational phenomena. They suggest to understand organization as an adverb (Schoeneborn et al. 2019). The organization is what characterizes the organizing process (in the same way that the adverb is what characterizes the verb). The organization is what qualifies the activities. An organization is not an entity but the very definition of the activity (goal, purpose, roles, actors, coordination modes, etc.). The authors invite us to rethink dynamics such as collective identity, actorhood and the interconnected instances of decision-making in fluid organizations (Dobusch and Schoeneborn 2015). This approach recognizes the existence of organizational dynamics in fluid organizational phenomena, but emphasizes their emergent, openness and situated nature. These authors 


\section{From Innovations at Work to Innovative Ways...}

propose an interesting approach, as understanding organization as an adverb is a stimulating way to study how organizational dynamics are produced and reproduced by actors, whichever their activities and their interrelatedness with all aspects of actors' life. This approach offers an alternative way to analyze organizational identity, actorhood and decisionmaking without necessarily ascribing mechanisms to actors.

\section{Events-Based Approach: Understanding Organization as a Temporality}

As an attempt to offer an alternative way of thinking and studying organization, Hernes (2014a, b) has suggested to focus on events and tempo735 rality. Based on this, Hussenot and Missonier (2016), Hussenot (2019), 736 Hussenot et al. (2020) have developed the events-based approach. It sug737 gests that organizational phenomena are temporal, emerge and are main738 tained through the ongoing configuration and co-definition of past, 739 present and future events that define both the current moment and the 740 continuity of the activity. The events-based approach suggests to shift 741 from an essentialist view of organization - that is a view reducing organi742 zation to an entity delimited in space and time - to a view in which the 743 organization is a shared history, past, present and future, that enables 744 actors to act collectively. In such a view, 'things' such as rules, technolo745 gies, actors and so on gain a meaning, a role and a status through this enacted temporality. Any 'thing' is understood as a temporal phenome746 non. Conversely, these 'things' also participate in the co-definition and 747 configuration of the past, present and future events (Hussenot 2019) and 748 organization is defined as a structure of events (Hernes 2014b). By 749 reframing ontological categories (events and not things) and the onto750 logical dimension (situated temporality and not time and space) of orga751 nizational phenomena, the events-based approach offers an alternative to 752 understand phenomena in which there is no given space, boundaries, 753 members and so on; but a continuous movement of defining activities in 754 which various actors, technologies, goals, histories and so on are delin755 eated through a shared temporality. The events-based approach is an 756 attempt to study these liquefied, nomadic and rhizomic contemporary organizational phenomena. 


\section{Arena and A. Hussenot}

760

761

762

763

764

765

766

767

768

769

770

771

772

773

AG+74

775

776

777

778

779

780

781

782

783

784

785

786

787

788

789

790

791

792

\section{Conclusion}

Based on a historical perspective, the aim of this chapter was to enquire about the way innovations at work have influenced organization theories over time. By focusing on the interrelations between technological innovations, the evolution of organizational phenomena and evolutions of ways of working, we have argued that organization theories have evolved along with innovations at work. This historical attempt opens new avenues of research in both organization studies and organizational history which could provide a better understanding of current work practices as being part of a more 'longue durée' phenomenon in line with the evolution of capitalism. For example, longitudinal studies and monographs on the evolution of work practices in companies could provide further material to think about current and future work practices as evolutions anchored into past transformations.

\section{References}

Acquier, A., Daudigeos, T., \& Pinkse, J. (2017). Promises and paradoxes of the sharing economy: An organizing framework. Technological Forecasting and Social Change, 125, 1-10.

Adler, P., Forbes, L. C., \& Willmott, H. (2008). Critical management studies. The Academy of Management Annals, 1(1), 119-180.

Alvesson, M., \& Wilmott, H. (1992). Critical management studies. London: Sage. Aoki, M. (1990). Toward an economic model of the Japanese firm. Journal of Economic Literature, 28(1), 1-27.

Arena, L. (2011). Les modèles nationaux d'enseignement de la gestion d'entreprise: Formes de capitalisme et modes d'organisation. Entreprises et Histoire, 65(4), 6-10.

Barad, K. (2003). Posthumanist performativity: Toward an understanding of how matter comes to matter. Signs-Journal of Women in Culture and Society, 28(3), 801-831.

Barad, K. (2007). Meeting the universe halfway: Quantum physics and the entanglement of matter and meaning. Durham, NC: Duke University Press.

Barnard, C. I. (1968/1938). The functions of the executive. Cambridge, MA: Harvard University Press. 


\section{From Innovations at Work to Innovative Ways...}

Bauman, Z. (2000). Liquid modernity. Cambridge, UK: Polity Press. 793 Bergson, H. (2009/1907). L'évolution créative. Paris: Presses Universitaires 794 de France.

Blagoev, B., Costas, J., \& Kärreman, D. (2019). We are all 'herd animals': 796 Community and organizationality in coworking spaces. Organization, 797 26(6), 894-916.

798

Bourdieu, P. (1972). Esquisse d'une théorie de la pratique. Paris: Le point. 799

Bourdieu, P. (1980). Le sens pratique. Paris: Les Éditions de Minuit. 800

Burrell, G. (1994). Modernism, post modernism, and organizational analysis: 801 The contribution of Jürgen Habermas. Organization Studies, 15(1), 1-19. 802

Cabantous, L., \& Sergi, V. (2018). Seeing the potentialities at the intersection: 803 A reflection on performativity and processuality mindsets.M@n@gement, 804 21(4), 1229-1243.

805

Chandler, A. D. (1990). Strategy and structure: Chapters in the history of the 806 industrial enterprise. Cambridge: MIT Press. 807

Chevalier, J. (1937). La technique de l'organisation des entreprises-Livre 1: Le 808 gouvernement de l'entreprise. Paris: Dunod. 809

Chia, R. (1995). From modern to postmodern organizational analysis. 810 Organization Studies, 16(4), 579-604. 811

Chia, R. (1997). Essai-Thirty years on: From organizational structures to the 812 organization of thought. Organization Studies, 18(4), 684-707. 813

Chia, R. (1999). A 'rhizomic' model of organizational change and transforma- 814 tion: Perspective from a metaphysics of change. British Journal of Management, 815 10(3), 209-227. $\quad 816$

Chia, R. (2003). Organization theory as postmodern science. In H. Tsoukas \& 817 C. Knudsen (Eds.), The Oxford handbook of organization theory (pp. 113-142). 818 Oxford: Oxford University Press. 819

Clegg, S. R. (1990). Modern organizations: Organization studies in the postmod- 820 ern world. London: Sage. 821

Cooper, R. (1976). The open field. Human Relations, 29(11), 999-1017. 822

Cooper, R. (1989). Modernism, post modernism and organizational analysis: 823 The contribution of Jacques Derrida. Organization Studies, 10(4), 479-502. 824

Cooper, R. (2005). Relationality. Organization Studies, 26(11), 1689-1710. 825

Cooper, R. (2007). Organs of process: Rethinking human organization. 826 Organization Studies, 28(10), 1547-1573. 827

Cooper, R. (2014). Process and reality. In J. Helin, T. Hernes, D. Hjort, \& 828 R. Holt (Eds.), Process philosophy and organization studies (pp. 585-604). 829 Oxford: Oxford University Press. 


\section{Arena and A. Hussenot}

831

832

833

834

835

836

837

838

839

840

841

842

843

844

845

846

847

848

849

850

851

852

853

854

855

856

857

858

859

860

861

862

863

864

865

866

867

868

Cooper, R., \& Burrell, G. (1988). Modernism, postmodernism and organizational analysis: An introduction. Organization Studies, 9(1), 91-112.

Cooren, F., Kuhn, T., Cornelissen, J. P., \& Clark, T. (2011). Communication, organizing and organization: An overview and introduction to the Special Issue. Organization Studies, 32(9), 1149-1117.

Corradi, G., Gherardi, S., \& Verzelloni, L. (2010). Through the practice-lens: Where is the bandwagon of practice-based studies heading? Management Learning, 41(3), 265-283.

Cortada, J. (2011). Information and the modern corporation. Cambridge, MA: MIT Press.

Cyert, R., \& March, J. (1963). A behavioral theory of the firm. Englewood Cliffs, NJ: Prentice Hall.

De Vaujany, F. X., Dameron, S., \& Rouleau, L. (2016a). Introduction au tournant pratique. In F. X. De Vaujany, A. Hussenot, \& J.-F. Chanlat (Eds.), Théories des organisations: nouveaux tournants (pp. 25-42). Paris: Economica. De Vaujany, F. X., Hussenot, A., \& Chanlat, J. F. (Eds.). (2016b). Théories des organisations: nouveaux tournants. Paris: Economica.

DiMaggio, P. J., \& Powell, W. W. (1983). The iron cage revisited: Institutional isomorphism and collective rationality in organizational fields. American Sociological Review, 48(2), 147-160.

Dobusch, L., \& Schoeneborn, D. (2015). Fluidity, identity, and organizationality: The communicative constitution of anonymous. Journal of Management Studies, 52(8), 1005-1035.

Duffy, B. E. (2016). The romance of work: Gender and aspirational labour in the digital culture industries. International Journal of Cultural Studies, $19(4), 441-457$.

Fayol, H. (1916/1949). General and industrial management (translated from Administration industrielle et générale). London: Pitman \& Sons.

Foucault, M. (1980). Power/knowledge: Selected interviews and other writings 1972-1977. London: Harvester.

Friedland, R., \& Alford, R. R. (1991). Bringing society back in: Symbols, practices, and institutional contradictions. In W. W. Powell \& P. J. DiMaggio (Eds.), The new institutionalism in organizational analysis (pp. 232-263). Chicago, IL: University of Chicago Press.

Gherardi, S. (2012). How to conduct a practice-based study: Problems and methods. Cheltenham, UK: Edward Elgar Publishing.

Giddens, A. (1979). Central problems in social theory. Berkeley, CA: University of California Press. 


\section{From Innovations at Work to Innovative Ways...}

Giddens, A. (1984). The constitution of society. Berkeley, CA: University of 869 California Press.

Gond, J.-P., Cabantous, L., Harding, N., \& Learmonth, M. (2016). What do 871 we mean by performativity in organizational and management theory? The uses and abuses of performativity. International Journal of Management Reviews, 18(4), 440-463.

Greenwood, R., \& Devine, K. (1997). Inside Aston: A conversation with Derek Pugh. Journal of Management Inquiry, 6(3), 200-208.

Haug, C. (2013). Organizing spaces: Meeting arenas as a social movement infrastructure between organization, network, and institution. Organization Studies, 34(5-6), 705-732.

Helin, J., Hernes, T., Hjorth, D., \& Holt, R. (Eds.). (2014). Oxford handbook of 879 process philosophy and organization studies. Oxford: Oxford University Press. 880 Hernes, T. (2014a). A process theory of organization. Oxford: Oxford University Press.

Hernes, T. (2014b). Alfred North Whitehead. In J. Helin, T. Hernes, D. Hjorth, $\&$ R. Holt (Eds.), Oxford handbook of process philosophy and organization studies (pp. 255-271). Oxford: Oxford University Press.

Hickson, D. J., \& Pugh, D. S. (2007/1964). Writers on organizations (6th ed.). London: Penguin Business.

Hussenot, A. (2019). L'organisation à l'épreuve des makers. Propositions pour une 888 approche par les événements. Laval, Québec: Presses Universitaires de Laval. organization studies: An events-based approach. Organization Studies, 37(4), 523-546.

Hussenot, A., \& Sergi, V. (2018). Collaborating without formal organization. In C. Cézanne \& L. Saglietto (Eds.), Human capital-intensive firms (pp. 53-72). Hershey, PA: IGI Global Publications.

894

895

Hussenot, A., de Vaujany, F. X., \& Chanlat, J.-F. (2016). Changements socio897 économiques et théories des organisations. In F. X. De Vaujany, A. Hussenot, \& J.-F. Chanlat (Eds.), Théories des organisations: nouveaux tournants (pp. 11-21). Paris: Economica.

898

899 900

Hussenot, A., Hernes, T., \& Bouty, I. (2020). Studying organization from the perspective of the ontology of temporality: Introducing the events-based 901 approach. In J. Reinecke, R. Suddaby, A. Langley, \& H. Tsoukas (Eds.), About time: Temporality and history in organization studies. Oxford: Oxford 902 903 904 


\section{Arena and A. Hussenot}

906

907

908

909

910

911

912

913

914

915

916

917

918

919

920

921

922

923

924

925

926

927

928

929

930

931

932

933

934

935

936

937

938

939

940

941

942

943

944

Introna, L. D. (2013). Otherness and the letting-be of becoming: Or, ethics beyond bifurcation. In P. R. Carlile, D. Nicolini, A. Langley, \& H. Tsoukas (Eds.), How matter matters: Objects, artifacts, and materiality in organization studies (pp. 260-288). Oxford: Oxford University Press.

Jensen, A., Thuesen, C., \& Geraldi, J. (2016). The projectification of everything: Projects as a human condition. Project Management Journal, 47(3), 21-34.

Jones, M. (2013). Untangling materiality. In P. R. Carlile, D. Nicolini, A. Langley, \& H. Tsoukas (Eds.), How matter matters: Objects, artifacts, and materiality in organization studies (pp. 197-226). Oxford: Oxford University Press.

Langley, A., \& Tsoukas, H. (2010). Introducing perspectives on process organization studies. In T. Hernes \& S. Maitlis (Eds.), Process, sensemaking and organizing (pp. 1-26). Oxford: Oxford University Press.

Latour, B. (2005). Reassembling the social. In An introduction to actor-networktheory. Oxford: Oxford University Press.

Lave, J., \& Wenger, E. (1991). Situated learning: Legitimate peripheral participation. Cambridge: Cambridge University Press.

Lazonick, W. (2010). Innovative business models and varieties of capitalism: Financialization of the U.S. Corporation. Business History Review, 84(4), 675-702.

Lounsbury, M., \& Crumley, E. T. (2007). New practice creation: An institutional perspective on innovation. Organization Studies, 28(7), 993-1012.

Lounsbury, M., \& Zhao, Y. E. (2014). Neo-institutional theory (Management Oxford bibliographies). Oxford: Oxford University Press.

Lyotard, J. F. (1979). La Condition postmoderne. Paris: Les Éditions de Minuit. March, J. \& Simon H. A. (1958). Organizations. Wiley: Blackwell Business.

McWilliams, D. (2015). Flat white economy: How the digital economy is transforming London \& other cities of the future. New York: Harry N. Abrams. Merton, R. (1949/1968). Social theory and social structure. New York: Free Press. Meyer, J. W., \& Rowan, B. (1977). Institutionalized organizations: Formal structure as myth and ceremony. American JournalofSociology, 83(2), 340-363. Minkes, L. (2011). Early years in University development in management education: Reflections and reminiscences on the University of Birmingham (1950s-1970s). Entreprises et Histoire, 65(4), 83-95.

Moriguchi, C. (2000). The evolution of employment relations in U.S. and Japanese manufacturing firms, 1900-1960: A comparative historical and institutional analysis, Working Paper Series, WP 7939. Cambridge, MA: National Bureau of Economic Research. 


\section{From Innovations at Work to Innovative Ways...}

Nash, C., Jarrahi, M. H., Sutherland, W., \& Phillips, G. (2018). Digital nomads beyond the buzzword: Defining digital nomadic work and use of digital technologies. In G. Chowdhury, J. McLeod, V. Gillet, \& P. Willett (Eds.), Transforming digital worlds. iConference 2018 (Lecture notes in computer science, vol. 10766). Cham, Switzerland: Springer.

Nutt, P. C. (1984). Types of organizational decision processes. Administrative Science Quarterly, 29(3), 414-450.

Orlikowski, W. J. (2000). Using technology and constituting structures: A practice lens for studying technology in organizations. Organization Science, 11(4), 404-428.

Orlikowski, W. J., \& Scott, S. V. (2008). Sociomateriality: Challenging the separation of technology, work, and organization. The Academy of Management Annals, 2(1), 433-474.

Osterman, P. (1991). Impact of IT on jobs and skills. In M. S. Scott Morton (Ed.), The Corporation of the 1990s-Information technology and organizational transformation (pp. 220-243). Oxford: Oxford University Press.

Parker, M. (1992). Post-modern organizations or postmodern organization theory. Organization Studies, 13(1), 1-17.

Parsons, T. (1942). Max Weber and the contemporary political crisis. The Review of Politics, 4(2), 155-172.

Parsons, T. (1947). Introduction. In A. M. Henderson \& T. Parsons (Eds.), Max Weber: The theory of social and economic organization (pp. 1-11). New York: Free Press.

Penrose, E. (1959). The theory of the growth of the firm. Oxford: Oxford University Press.

Pickering, A. (1995). The mangle of practice: Time, agency, and science. Chicago, IL: The University of Chicago Press.

Porter, M. E., \& Heppelman, J. E. (2014). How smart and connected objects are transforming competition. Harvard Business Review, 92(11), 64-88.

Pugh, D. S., \& Hickson, D. J. (1972). Causal inference and the Aston studies. Administrative Science Quarterly, 17(2), 273-276.

Rantakari, A., \& Vaara, E. (2017). Narratives and processuality. In A. Langley $\&$ H. Tsoukas (Eds.), The Sage handbook of process organization studies (pp. 271-285). London: Sage.

Rao, H. (1994). The social construction of reputation: Certification contests, 978 legitimation, and the survival of organizations in the American automobile industry; 1895-1912. Strategic Management Journal, 15(1), 29-44. 


\section{Arena and A. Hussenot}

982

983

984

985

986

987

988

989

990

991

992

993

994

995

996

997

998

999

1000

1001

1002

1003

1004

1005

1006

1007

1008

1009

1010

1011

1012

1013

1014

1015

1016

1017

1018

1019

Rescher, N. (1996). Process metaphysics: An introduction to process philosophy. Albany, NY: State University of New York Press.

Rescher, N. (2001). Process philosophy: A survey of basic issues. Pittsburgh, CA: University of Pittsburgh Press.

Schatzki, T. R. (1996). Social practices: A Wittgensteinian approach to human activity and the social. Cambridge, UK: Cambridge University Press.

Schatzki, T. R. (2001). Introduction. Practice theory. In T. R. Schatzki, K. Knorr-Cetina, \& E. von Savigny (Eds.), The practice turn in contemporary theory (pp. 1-14). London: Routledge.

Schoeneborn, D., \& Scherer, A. G. (2012). Clandestine organizations, al Qaeda, and the paradox of (in)visibility: A response to Stohl and Stohl. Organization Studies, 33(7), 963-971.

Schoeneborn, D., Kuhn, T. R., \& Kärreman, D. (2019). The communicative constitution of organization, organizing, and organizationality. Organization Studies, 40(4), 475-496.

Schreyögg, G., \& Sydow, J. (2010). Organizing for fluidity? Dilemmas of new organizational forms. Organization Science, 21(10), 1251-1262.

Scott, W. G. (1992). Chester I. Barnard and the guardians of the managerial state. Lawrence, KS: Kansas University Press.

Scott Morton, M. S. (Ed.). (1991). The corporation of the 1990s: Information technology andorganizational transformation. Oxford: Oxford University Press. Selznick, P. (1943). An approach to a theory of bureaucracy. American Sociological Review, 8(1), 47-54.

Selznick, P. (1948). Foundations of the theory of organization. American Sociological Review, 13(1), 25-35.

Shenhav, Y. (2003). The historical and epistemological foundations of organization theory: Fusing sociological theory with engineering discourse. In H. Tsoukas \& C. Knudsen (Eds.), The Oxford handbook of organization theory (pp. 183-209). Oxford: Oxford University Press.

Shotter, J. (2013). Reflections on sociomateriality and dialogicality in organization studies: From 'inter-' to 'intra-thinking'... in performing practices. In P. R. Carlile, D. Nicolini, A. Langley, \& H. Tsoukas (Eds.), How matter matters: Objects, artifacts, and materiality in organization studies (pp. 32-57). Oxford: Oxford University Press.

Simon, H. (1947). Administrative behavior: A study of decision-making processes in administrative organization. New York: Macmillan.

Slappendel, C. (1996). Perspectives on innovation in organizations. Organization Studies, 17(1), 107-129. 
Slife, B. D. (2004). Taking practice seriously: Toward a relational ontology. 1020 Journal of Theoretical and Philosophical Psychology, 24(2), 158-178. 1021

Stohl, C., \& Stohl, M. (2011). Secret agencies: The communicative constitution 1022 of a clandestine organization. Organization Studies, 32(9), 1197-1215. 1023

Taylor, F. W. (1911). Principles of scientific management. New York \& London: 1024 Harper \& Brothers Publishers.

1025

Taylor, C. (1995). Philosophical arguments. Cambridge, MA: Harvard 1026 University Press. 1027

Tsoukas, H., \& Chia, R. (2002). On organizational becoming: Rethinking 1028 organizational change. Organization Science, 13(5), 567-582. 1029

Weber, M. (1922 [1978]). Economy and society. Berkeley, CA: University of 1030 California Press. 1031

Whilston, K. (1997). The reception of scientific management by British engi- 1032 neers: 1890-1914. Business History Review, 71(2), 207-229. 1033

Wilhoit, E. D., \& Kisselburgh, L. G. (2015). Collective action without organi- 1034 zation: The material constitution of bike commuters as collective. Organization 1035 Studies, 36(5), 573-592. 1036

Yousfi, H. (2013). Rethinking hybridity in postcolonial contexts: What changes 1037 and what persists? The Tunisian case of Poulina's managers. Organization 1038 Studies, 35(3), 393-421. 


\section{Author Queries}

Chapter No.: 15

0005013045

\begin{tabular}{|c|c|c|}
\hline Queries & Details Required & Author's Response \\
\hline AU1 & $\begin{array}{l}\text { Refs. "George 1968; Wren 1972" are cited in text but not } \\
\text { provided in the reference list. Please provide details in the } \\
\text { list or delete the citation from the text. }\end{array}$ & \\
\hline AU2 & $\begin{array}{l}\text { Please note that single quote marks have been made } \\
\text { consistent for emphasis and double quotes for cited/quoted } \\
\text { text. Please check and confirm if edits are okay }\end{array}$ & \\
\hline AU3 & $\begin{array}{l}\text { Please check and confirm if change in quote marks in the } \\
\text { sentence "The initial essentialist view of } \\
\text { organizationessentialist view of organization..." is okay. Or } \\
\text { should double quote marks be retained if the text is cited } \\
\text { material? }\end{array}$ & \\
\hline AU4 & $\begin{array}{l}\text { Please check we have retained the variant spelling } \\
\text { «towards « throughout this chapter. }\end{array}$ & \\
\hline AU5 & $\begin{array}{l}\text { Please check and confirm if "repertories" in the quoted part } \\
\text { in the sentence "As early as the } 1960 \text { s, these authors..." is } \\
\text { written as it is in the original text }\end{array}$ & \\
\hline AU6 & $\begin{array}{l}\text { Please provide closing double quotes in the sentence "In } \\
\text { this sense, the Aston Group's contribution to organization } \\
\text { theory also has...." }\end{array}$ & \\
\hline AU7 & $\begin{array}{l}\text { The citation "Barnard, } 1938 \text { " has been changed to } \\
\text { "Barnard, 1968/1938" to match the author name/date in the } \\
\text { reference list. Please check if the change is fine in this } \\
\text { occurrence and modify the subsequent occurrences, if } \\
\text { necessary. }\end{array}$ & \\
\hline AU8 & $\begin{array}{l}\text { The citation "Power \& DiMaggio 1983" has been changed } \\
\text { to "DiMaggio and Powell, 1983" to match the author } \\
\text { name/date in the reference list. Please check if the change } \\
\text { is fine in this occurrence and modify the subsequent } \\
\text { occurrences, if necessary. }\end{array}$ & \\
\hline AU9 & $\begin{array}{l}\text { The citation "Meyer \& Ronan, } 1977 \text { " has been changed to } \\
\text { "Meyer and Rowan, 1977" to match the author name/date } \\
\text { in the reference list. Please check if the change is fine in } \\
\text { this occurrence and modify the subsequent occurrences, if } \\
\text { necessary. }\end{array}$ & \\
\hline AU10 & $\begin{array}{l}\text { The citation "Porter \& Heppelman, 2015" has been } \\
\text { changed to "Porter and Heppelman, 2014" to match the } \\
\text { author name/date in the reference list. Please check if the } \\
\text { change is fine in this occurrence and modify the subsequent } \\
\text { occurrences, if necessary. }\end{array}$ & \\
\hline
\end{tabular}




\begin{tabular}{|l|l|l|}
\hline AU11 & $\begin{array}{l}\text { The citation "Cabantous \& Sergi, 2019" has been changed } \\
\text { to "Cabantous and Sergi, 2018" to match the author name/ } \\
\text { date in the reference list. Please check if the change is fine } \\
\text { in this occurrence and modify the subsequent occurrences, } \\
\text { if necessary. }\end{array}$ & $\begin{array}{l}\text { The citation "Bergson, 1907" has been changed to } \\
\text { "Bergson, 2009/1907" to match the author name/date in } \\
\text { the reference list. Please check if the change is fine in this } \\
\text { occurrence and modify the subsequent occurrences, if } \\
\text { necessary. }\end{array}$ \\
\hline AU12 & $\begin{array}{l}\text { The citation "1990" has been changed to "Bourdieu, 1980" } \\
\text { to match the author name/date in the reference list. Please } \\
\text { check if the change is fine in this occurrence and modify } \\
\text { the subsequent occurrences, if necessary. }\end{array}$ & \\
\hline AU13 & $\begin{array}{l}\text { The citation "1990" has been changed to "Bourdieu, 1980" } \\
\text { to match the author name/date in the reference list. Please } \\
\text { check if the change is fine in this occurrence and modify } \\
\text { the subsequent occurrences, if necessary. }\end{array}$ & \\
\hline AU15 & $\begin{array}{l}\text { Please note that double quotes have been changed to single } \\
\text { in the sentence 'This has been called...' and its subsequent } \\
\text { sentences. Please check if okay. Or should original be } \\
\text { retained if phrases are cited material }\end{array}$ & \\
\hline AU17 & $\begin{array}{l}\text { References "Hussenot et al. (2016), Lounsbury \& Crumley } \\
\text { (2007)" were not cited anywhere in the text. Please provide } \\
\text { in text citation or delete the reference from the reference list. }\end{array}$ & \\
\hline Please update "Forthcoming". \\
\hline
\end{tabular}

